\title{
Groups of Companies, Cash Holdings Level and Credit Risk
}

\author{
Xiaofeng Xie \\ School of Management and Economics \\ University of Electronic Science and Technology of China \\ General Education Department \\ Chengdu Neusoft University \\ Sichuan,China \\ Yang Yang* \\ School of Economics Mathematics \\ Southwestern University of Finance and Economics \\ yy@swufe.edu.cn
}

\author{
Kai Xu \\ School of Management and Economics \\ University of Electronic Science and Technology of China \\ School of Business \\ Chengdu University \\ Sichuan,China \\ Zongfang Zhou \\ School of Management and Economics \\ University of Electronic Science and Technology of China \\ Sichuan,China
}

\begin{abstract}
Based on KMV model, this paper empirically studies the internal relationship between groups of companies, cash holdings level and credit risk, and tentatively explores the intrinsic mechanism between cash holdings and credit risk of state-owned groups of companies. The research shows that :(1) compared with companies with independent legal persons, the cash holdings level of listed subsidiaries of groups of companies is lower, and the cash holdings level of state-owned and private groups of companies is significantly different;(2) the cash holdings level of listed companies is negatively correlated with the credit risk, but the state-owned ownership property weakens the relationship;(3) at the groups of companies level, the negative correlation between cash holdings level and credit risk is only maintained in the groups of companies with private ownership property.
\end{abstract}

Keywords-Groups of companies; Cash holdings level; Credit risk; Ownership property

\section{INTRODUCTION}

An group of companies is defined as an independent legal entity connected by formal or informal ties with a common program or goal [1]. Studies have shown that groups of companies play an important role in all economies, especially in emerging economies. The internalization of the industrial chain of groups of companies can make up the low efficiency of market allocation to some extent, which plays an important role in optimizing economic structure and promoting economic growth [2]. China's groups of companies have grown rapidly since the Reform and Opening-up. From the list of China's top 500 enterprises published by Fortune China in 2014, we can see that there are 416 groups of companies, accounting for more than $80 \%$ of the total number of enterprises. Compared with the proportion of China's top 500 enterprises in 2010, the proportion of groups of companies has increased by 6 percentage points [3]. However, it is not easy to understand the efficiency and economic consequences of groups of companies. A large number of scholars provide inconsistent empirical evidence to prove that the efficiency and economic consequences of groups of companies are contingency [4-7]. The reasons may be different according to different research perspectives, but there is still a lack of unified theoretical framework. Different literatures even provide contradictory empirical results in the same background [8].

The theoretical analysis of corporate cash holdings is an principle and influence of a company's cash holdings [9]. For an independent company, according to the precautionary theory of cash holdings, cash holdings can effectively prevent the adverse impact of external environment on the company, increase the financial flexibility of the company and avoid financial crisis caused by cash flow problems. Therefore, the company's higher cash holdings level can resist the adverse impact of the external market and effectively reduce its own credit risk. However, for groups of companies, the relationship between cash holdings and credit risk seems not so intuitive. The biggest difference between a company under the control of an groups of companies and an independent company is that an groups of companies can use its internal capital market to redeploy resources [10]. In other words, for companies under the control of groups of companies, even if their own cash holdings are low, when they encounter external adverse shocks, it is possible to mobilize funds efficiently through the internal capital market, thus weakening the impact of these adverse shocks on the company. Therefore, for companies under the control of groups of companies, they only need lower level of cash holdings to maintain the same level of credit risk. Secondly, The impact of property rights is significant.On the one hand, due to state-owned capital endorsement and soft budget constraints [11], those state-owned groups of companies can provide low-cost capital support for their subsidiaries more efficiently. That is to say, for companies under state-owned groups of companies, the incremental effect of cash holdings should be greater than that of privately controlled groups of companies. In other words, state-owned property rights should show a significant positive adjustment relationship between cash holdings and credit risks. On the other hand,a large number of literatures have emphasized that ancient topic, and many scholars have studied the motivation, 
the agency problem of state-owned property rights is more likely than that of private property rights due to the absence of owner subject and imperfect decision-making process [12]. In addition to the preventive theory, some scholars also put forward the agent theory of cash holdings. That is, cash is an asset that is easier to dispose of and seize than other assets. Managers may achieve the goal of embezzlement by maintaining a high level of cash holdings. Therefore, this provides a completely opposite explanation for the status of the property nature of state-owned property in the relationship between cash holdings and credit risk. That is, the state-owned property right should show a significant negative adjustment relationship between cash holdings and credit risk. Finally, at the level of groups of companies, if state-owned property rights are always accompanied by management agency problems, and groups of companies are more likely to conceal management encroachment due to their complex internal relations [13]. Therefore, when state-owned groups of companies show more serious agency problems, the relationship between cash holdings and credit risks of groups of companies is worth reassessing.

Therefore, in order to answer these questions systematically, the data of a-share listed companies in Shanghai and shenzhen from 2011-2016 were used to define the groups of companies from the perspective of ultimate controller. Secondly, it compares the cash holdings level of the independent listed company and the groups of companies under the control of the state-owned groups of companies and the listed company under the control of the private groups of companies. Then, the relationship between cash holdings and credit risk of listed companies belonging to groups of companies and the adjustment of property rights are investigated. Finally, it tries to explore the relationship between cash holdings and credit risk and the underlying mechanism at the level of groups of companies. Except for part I introduction; The second part is the research design of this paper; The third part is the empirical conclusions and analysis; The last part is the conclusions.

\section{RESEARCH DESIGN}

\section{A. Samples and Data}

We taken the A-share listed companies in Shanghai and shenzhen from 2011 to 2016 as the initial samples of the study, and delete (1) listed companies in financial industry; (2) listed companies less than one year; (3) listed companies with missing data. Finally, 212 listed companies were obtained, with a total of 1272 year-company research samples. In order to compare the listed companies affiliated to the groups of companies with the independent listed companies. The 212 listed companies were paired and selected according to the following principles: (1) close listing time; (2) same or similar industry type; (3) similar asset scale. The research data mainly comes from the CSMAR database.

\section{B. The Definition of Groups of Companies}

Drawing on the work of Khanna and Rivkin(2001)[1] and W.X. Cai et al. (2015)[14], if the ultimate controller of a listed company controls two or more listed companies in the same year, the ultimate controller is regarded as the controller of the groups of companies. The listed company is also considered to be a listed company under the groups of companies. Furthermore, if the ultimate controller is the government at all levels, relevant ministries and commissions under the state council and subordinate institutions (such as the Ministry of Finance and the SASAC), the groups of companies represented by the controller is considered as the nature of state-owned property rights; Otherwise it is considered as the nature of private property rights. In defining the groups of companies, we adopted a random sampling and tracing method from the pool of listed companies.

\section{Measurement of Cash Holdings}

Referring to the relevant work of Opler et al. (1999)[15], cash holdings are defined as follows:

Cash holdings $=$ cash and cash equivalents/(total assets cash and cash equivalents)

\section{Measurement of Credit Risk}

The measurement of credit risk has been studied in many literatures. A series of different types of methods including zscore [16], Logit[17], Probit[18], neural network [19] and rough set [20] have been proposed and improved by many scholars to adapt to the measurement of credit risk under different application situations. Since the data in this paper come from the a-share listed companies in Shanghai and shenzhen, the data from the securities market can more effectively reflect the changes of their credit risk. Therefore, we choose KMV model as the evaluation method of credit risk and use the probability of default EDF as the measurement of credit risk in this paper.

According to the KMV model, value change follows the set Brownian motion. Which is

$$
V=V_{0} N\left(d_{1}\right)-D P \times e^{-r t} N\left(d_{2}\right)
$$

$$
\begin{gathered}
\text { Where } d_{1}=\frac{\ln \left(V_{0} / D P\right)+\left(r+\frac{1}{2} s_{V}^{2}\right) T}{s_{V} \sqrt{T}}, \\
d_{2}=d_{1} \rightarrow s_{V} \sqrt{T} s_{E}=\frac{V_{0} N\left(d_{1}\right)_{S}}{V} .
\end{gathered}
$$

Therefore, the probability of default is

$$
E D F=1-N(D D), D D=\frac{V_{0}-D P}{V_{0}} s_{V}
$$




\section{E. Model Setting}

To examine the problems mentioned above, models 1 are established

$$
\text { Cashingholdings }=a_{0}+a \text { Group }+X b+e
$$

In (4), $\mathrm{X}$ represents the control variable selected in this paper. Referring to the work of Dittmar et al. (2003)[21], control variables include working capital ratio (Wcap), company Size (Size), asset-liability ratio (Lev), capital expenditure ratio (Capex), operating(CashFlow), Dividend distribution(Dividend), equity concentration (EquFo), NetGrowth (NetGrowth) and receivables Turnover (Turnover).

In order to analyze the differences of cash holdings between listed companies affiliated to state-owned groups of companies and private groups of companies, the interaction terms of group variables and ownership variables are added in model 1, model 2 is shown in (5) :

$$
\begin{aligned}
& \text { Cashingholdings }=a_{0}+a \text { Group }+g \text { Ownership }+ \\
& \text { i Ownership } \times \text { Group }+X b+e
\end{aligned}
$$

Further, in order to verify the relationship between cash holdings level and credit risk, models 3 and 4 were established. These are shown in (6) and (7).

$$
\text { CreditRisk }=a_{0}+a \text { Cashingholdings }+X b+e
$$

\section{CreditRisk $=a_{0}+a$ Cashingholdings $+g$ Ownership h Ownership $\times$ Cashingholdings $+X b$ te}

In model 3 , if the coefficient of Cashingholding variable is significantly negative, it verifies the precautionary theory of cash holdings. If the coefficient of Cashingholding variable is positive, it indicates that credit risk increases with the increase of cash holdings level, which may be a sign of the agent theory of cash holdings. Model 4 adds interactive terms of cash holdings level and ownership on the basis of model 3. On the premise that the coefficient of variable coefficient is significantly negative, if the coefficient of variable coefficient in model 4 is significantly regular, it means that the nature of state-owned property right weakens the negative impact of cash holdings level on credit risk. On the contrary, if the coefficient of variation in model 4 is significantly negative, it means that the property nature of state-owned property strengthens the negative impact of cash holdings level on credit risk.

It should be noted that the regression samples of model 1 and model 2 are 424 listed companies in the whole sample (2,544 samples in total: 1272 year-company samples of 212 listed companies belonging to groups of companies and 1272 year-company samples of 212 independent listed companies); Model 3 and model 4 respectively regress the 1272 yearcompany samples of 212 listed companies belonging to the groups of companies and 1272 year-company samples of 212 independent listed companies. Therefore, the comparison of regression results between model 3 and model 4 on the two samples will help us to explain the relationship between cash holdings and credit risk of listed companies belonging to groups of companies and independent listed companies, as well as the adjustment of such relationship by the nature of property rights.

Finally, model 3 is used again to explore the impact of property rights on the relationship between cash holdings and credit risk at the groups of companies level. We first trace 212 listed companies belonging to groups of companies, and define them as 67 groups of companies

groups of companies, accounting for $64 \%$. There are 24 privately controlled groups of companies, accounting for $36 \%$. Then, the statement of each groups of companies is consolidated, and the sum of cash holdings of all listed companies under the groups of companies is used as the cash holdings level of the groups of companies. The market volatility adjusted by the scale is used as the volatility of the groups of companies as mentioned above. Finally, model 3 was used to perform regression analysis on 258 annual samples of 43 state-owned groups of companies and 144 annual samples of 24 private groups of companies, and the regression results were compared.

\section{RESUlts AND ANALYSIS}

Table I shows the descriptive statistics of the main variables. The mean value of credit risk of all sample companies was 0.2673 and cash holding level was 0.2169, indicating that the cash holding level of sample companies was low and their credit risk was high. The mean value of enterprise groups is 0.158 , the maximum value is 1 , the minimum value is 0 , and the standard deviation is 0.6113 , indicating that the number of enterprise groups is small and most enterprises are independent listed companies.

For the panel data used in this paper, we use the Mixed Least Squares Estimation (pooled OLS) and Random Effect Model (RE) to estimate the method. Table II shows the full sample regression results of model 1 and model 2 under the Mixed Least Squares Estimate.

From the regression results in Table II, both model 1 and model 2 are well explained. The coefficient of Group variable in model 1 is significantly negative (estimated value is -0.0310 , $\mathrm{t}$ value is -5.72). This indicates that the cash holdings level of listed companies belonging to groups of companies is lower than that of independent listed companies. This is consistent with our expectations. When companies belonging to groups of companies are adversely impacted by the external market, the internal capital market of groups of companies will play an important role in allocating resources efficiently and buffering the adverse impact. The regression coefficient of the Group variable in model 2 is negative, the cross term coefficient of property rights and Group variable is positive which is 
inconsistent with our expectation. This means that even though the listed companies with state-owned property right endorsement have lower financing costs and convenience than the listed companies affiliated with private controlled groups of companies, the listed companies affiliated with state-owned groups of companies have larger cash holdings.

Table III shows the regression results of model 3 and model 4 under the Mixed least Squares Estimation in the samples of listed companies and independent listed companies of groups of companies.

Table III reveals the relationship between cash holdings and credit risk from the perspective of group and non-group samples, and the moderating effect of property rights. First, it can be seen from Table III that cash holdings in non-group samples have stronger explanatory power for credit risk. The impact of cash holdings of independent listed companies on credit risk is more explanatory than that of listed companies belonging to groups of companies. Secondly, the improvement of cash holdings of both listed companies and independent listed companies affiliated with groups of companies significantly reduces credit risk. For listed companies belonging to groups of companies, the regression coefficient of cash holdings is -0.0143 , while for independent listed companies, it is -0.0103. In other words, the marginal contribution of listed companies with groups of companies background to reducing credit risk is about $40 \%$ higher than that of independent listed companies. Finally, the state-owned property rights of both listed companies and independent listed companies belonging to groups of companies significantly weaken the buffer effect of cash holdings on credit risk. This weakening is even more pronounced for listed companies with a conglomerate background.

We further subdivided the sample in an attempt to examine the reasons for state controls to weaken the cushion of cash holdings against credit risk. The samples of listed companies with groups of companies background are divided into stateowned control and private control according to the property nature of the ultimate controller. With the regression of model 3 , the regression results are shown in Table IV.

TABLE I. DESCRIPTIVE STATISTICS OF MAIN VARIABLES

\begin{tabular}{|l|l|l|l|l|l|}
\hline \multicolumn{1}{|c|}{ Variable } & \multicolumn{1}{|c|}{ Mean } & \multicolumn{1}{c|}{ Minimum } & Maximum & Standard deviation \\
\hline EDF & 0.2673 & 0.0119 & 0.6033 & 0.0606 \\
\hline Cashinghlodings & 0.2169 & 0.0018 & 0.9293 & 0.1615 \\
\hline Group & 0.6085 & 0 & 1 & 0.3334 \\
\hline
\end{tabular}

TABLE II. REGRESSION RESULTS OF GROUPS OF COMPANIES, PROPERTY RIGHTS AND CASH HOLDINGS

\begin{tabular}{|c|c|c|}
\hline & Model 1 & Model 2 \\
\hline Group & $-0.0310 * * *$ & -0.0239 \\
\hline $\begin{array}{l}\text { Ownership } \times \text { Group } \\
\text { Wcap } \\
\text { Size } \\
\text { Lev } \\
\text { Capex } \\
\text { CashFlow } \\
\text { Constant } \\
\text { Observations } \\
\end{array}$ & $\begin{array}{l}0.0212 * * * \\
0.0049 * * * \\
-0.0523 * * * \\
-0.0058 * * * \\
0.8760 * * * \\
0.3161 * * * \\
2544\end{array}$ & $\begin{array}{l}0.0469 * * \\
0.0782 * * * \\
0.018 * * * \\
-0.0341 * * * \\
-0.0742 * * * \\
0.0967 * * * \\
2.3291 * * * \\
2544\end{array}$ \\
\hline R-Square & 0.4273 & 0.3892 \\
\hline
\end{tabular}

TABLE III. THE REGRESSION RESULTS OF CREDIT RISK, PROPERTY RIGHTS AND CASH HOLDINGS

\begin{tabular}{|c|c|c|c|c|}
\hline & Model 3 & Model 4 & Model 3 & Model 4 \\
\hline & (Group samples) & (Group samples) & (Non-group samples) & (Non-group samples) \\
\hline Cashinghlodings & $-0.0181 * * *$ & $-0.0143 *$ & $-0.0103 *$ & -0.0082 \\
\hline $\begin{array}{l}\text { Ownership } \times \text { Group } \\
\text { Wcap } \\
\text { Size } \\
\text { Lev } \\
\text { Capex } \\
\text { CashFlow } \\
\text { Constant } \\
\text { Observations } \\
\end{array}$ & $\begin{array}{l}0.4138 * * * \\
0.0032 * * * \\
0.0065 * * * \\
-0.0667 * * * \\
-0.0058 * * * \\
0.8760 * * * \\
1272\end{array}$ & $\begin{array}{l}1.2318 * * * \\
-0.3412 * * * \\
0.0091 * * * \\
-0.0731 * * * \\
-0.0058 * * * \\
0.1539 * * * \\
1272\end{array}$ & $\begin{array}{l}0.4875 * * * \\
0.0952 * * * \\
0.0137 * * * \\
-0.0614 * * * \\
-0.0058 * * * \\
0.7234 * * * \\
1272\end{array}$ & $\begin{array}{l}0.0469 * * \\
0.8916 * * * \\
-0.2390 * * * \\
0.0079 * * * \\
-0.1790 * * * \\
-0.0742 * * * \\
0.0917 * * * \\
1272\end{array}$ \\
\hline R-Square & 0.2113 & 0.2141 & 0.3921 & 0.3938 \\
\hline
\end{tabular}


TABLE IV. GROUP SAMPLE REGRESSION RESULTS OF CREDIT RISK AND CASH HOLDINGS

\begin{tabular}{|l|l|l|}
\hline & \multicolumn{1}{|c|}{ Model 3 } & Model 3 \\
\hline & \multicolumn{1}{|c|}{ (State control) } & (Private control) \\
\hline Cashinghlodings & -0.0114 & $-0.0209 * *$ \\
\hline Ownership $\times$ Group & & $0.0469^{* *}$ \\
Wcap & $0.0794^{* * *}$ & $0.0317^{* * *}$ \\
Size & $0.0056^{* * *}$ & $0.0233^{* * *}$ \\
Lev & $-0.0142^{* * *}$ & $-0.0438^{* * *}$ \\
Capex & $-0.0185^{* * *}$ & $-0.0247^{* * *}$ \\
CashFlow & $0.0060^{* * *}$ & $0.0506^{* * *}$ \\
Constant & $0.5135^{* * *}$ & $1.5237^{* * *}$ \\
Observations & 258 & 144 \\
\hline R-Square & & 0.1783 \\
\hline
\end{tabular}

It can be seen that after further refinement of the samples, the impact of cash holdings on credit risk of listed companies of state-owned groups of companies is no longer significant. In other words, the precautionary theory of cash holdings has been maintained only under private control.

\section{CONCLUSIONS}

As for the motivation of cash holdings, the precautionary theory holds that the improvement of cash holdings level can reduce the credit risk of the company; The agency theory suggests that cash or cash equivalents are more likely to be misappropriated than other assets, so higher levels of cash holdings may imply more serious agency problems. Agency theory predicts that the improvement of cash holdings will not reduce the credit risk and may even increase the credit risk of the company due to serious misappropriation. The literature does not provide empirical evidence. So Why are cash holdings held by Chinese companies? There is little literature on the subject and no empirical evidence on the subject. Considering the agency problem of state-owned property rights caused by the absence of owners for a long time and the organizational form of groups of companies, which is easier to hide embezzlement, this paper selects China's listed companies as samples to analyze the relationship between cash holdings and credit risk in the context of groups of companies and the impact of property rights on such relationship.

Firstly, by comparing the cash holding level of listed companies and independent listed companies affiliated to enterprise groups, this paper finds that the cash holding level of listed companies affiliated to enterprise groups is lower. This is in line with our expectations and explains the important role of the internal capital market of enterprise groups as the risk shield of member enterprises. At the same time, after adding property rights as the moderator, we found that collectivization under the state control contributes less to the reduction of cash holding level than collectivization under the private control. Of course, this can be attributed to two reasons. First, the efficiency of the internal capital market of the stateowned enterprise groups is lower than that of the private enterprise groups. Second, state-owned enterprise groups have a large number of financing advantages over private enterprise groups, so they are in a state of "no shortage of money" for a long time. Secondly, this paper examines the relationship between cash holdings and credit risk. Both the group sample and the non-group sample, the increase in cash holdings significantly reduces credit risk. This reveals one side of the precautionary theory of cash holdings. However, state control significantly reduces the contribution of cash holdings to reducing credit risk, especially for conglomerates. This may be due to the seriousness of the corporate agency problem. To this end, we further refine the sample. The group samples were further divided into state-owned control and private control, and the impact of cash holding level on credit risk was investigated. The regression results show that the group samples controlled by private enterprises maintain the precautionary theory of cash holdings, while the group samples controlled by state-owned enterprises prefer the agent theory of cash holdings. Therefore, we have reason to believe that the preventative interpretation of the cash holding motive, or agency interpretation, is a contingency process.

\section{ACKNOWLEDGMENT}

This study was supported by National Natural Science Foundation of China (No. 71271043\& No.71701066).

\section{REFERENCES}

[1] T. Khanna and J.W. Rivkin, "Estimating the performance effects of business groups in emerging markets," Strategic. Management Journal, vol. 22(1), pp. 45-74, 2001.

[2] T. Khanna and K. Palepu, "The future of business groups in emerging markets: long-run evidence from Chile," Academy of Management Journal, vol. 43(3), pp. 263-285, 2000.

[3] Y. Yang, Study on credit risk contagion and evolution mechanism of groups of companies, ChengDu: Doctorate Dissertation of University of Electronic Science and technology of China, 2015.

[4] K. Lins and H. Servaes, "International evidence on the value of corporate diversification," Journal of Finance, vol. 54(6), pp. 2215-2239, 1999.

[5] J. He, X. Mao, O. Rui, and X. Zha, "Business group in China," Journal of Corporate Finance, vol. 22, pp. 166-192, 2013.

[6] T. Khanna and Y. Yafeh, "Business groups in emerging markets: paragons or parasites?" Journal of Economic Literature, vol. 45(2), pp. 331-372, 2007.

[7] O. Dvouletý, "Can policy makers count with positive impact of entrepreneurship on economic development of the Czech regions?" Journal of Entrepreneurship in Emerging Economies, vol. 9(3), pp. 286299, 2017.

[8] M. Camey, D. Shapiro, and Y. Tang, "Business group performance in china: ownership and temporal consideration" Management and Organization Review, vol. 5(2), pp. 167-193, 2009. 
[9] J. M. Keynes, The general theory of employment, interest and money, McMillan, London, 1936.

[10] Y. Yang, Z.F. Zhou, and M. Xiao, "Study of mechanism of action between credit risk and moral hazard for business group" Journal of Systems Engineering, vol. 6(27), pp. 806-811, 2012.

[11] Z.Y. $\mathrm{Xu}$, "State-owned enterprise as policy instruments and SOE reform:perspective of soft budgets constraint," China Soft Science, vol. 3 , pp. 32-44, 2014.

[12] C. Zhang, "Agency cost of state-owned enterprises: the game model's deduction, optimal solution and analysis," Financial Accounting Analysis, vol. 11, pp. 52-54, 2016.

[13] K. H. Bae, J. K. Kang, and J. M. Kim, "Tunneling or value added? Evidence from mergers by Korean business groups," Journal of Finance, vol. 57(6), pp. 2695-2740, 2002.

[14] W.X. Cai, C. Zhen, and Z.Y. Hu, "Business groups ,monetary policy, and corporate cash holdings," Journal of Financial Research, vol. 2(416), pp. 114-130, 2015.
[15] T. Opler, L. Pinkowitz, R. Stulz, and R. Williamson, "The determinants and implications of corporate cash holdings," Journal of Financial Economics, vol. 52, pp. 3-46, 1999.

[16] D. Martin, "Early warning of bank failure: a logit regression approach," Journal of Banking and Finance, vol. 2, pp. 249-276, 1977.

[17] J.S. Ohlson, "Financial ratio and the probabilistic prediction of bankruptcy," Journal of Accounting Ressearch, vol. 19, pp. 109-131, 1980.

[18] M. Lundy, Cluster analysis in credits coring: credit scoring and credit control, Oxford University Press, New York, 1993.

[19] C.F. Huang, "Types of Credit Risks and Strategies to Improve Risk Identification by Internet of Intelligences," JRACR, vol. 3, pp. 44-51, 2013.

[20] M. Zhang and Z.F. Zhou, "A Credit Rating Model for Enterprises Based on Projection Pursuit and K-Means Clustering Algorithm," JRACR, vol. 2, pp. 131-138, 2012.

[21] A. Dittmar, J. Mahrt-Smith, and H. Servaes, "International corporate governance and corporate cash holdings," Journal of Financial and Quantitative, vol. 38, pp. 111-133, 2003. 